\title{
Editorial:
}

\section{The Emerging Constitution and the European Area of Justice}

\author{
Wolfgang Heusel ${ }^{*}$
}

As the "Convention on the Future of Europe" reached the end of its deliberations and presented its draft for a Constitution for the European Union to the European Council in Thessaloniki on 20 June 2003, it seems appropriate to reflect for a moment on the constitutional development of the EU and in particular on the future status of the area of "justice" which, curiously enough, in its German version is perceived as an area of "law" '.

I.

Since Maastricht, the nationals of EU Member States are, as defined by primary EU law, citizens of "an ever closer Union among the peoples of Europe"; in fact, the postulated perpetuity of the integration process between the countries of the European Union has found expression, even avant la lettre, in the state of permanent constitutional reform in which the EU has been for 20 years. The changes to the treaties since the Single European Act transcend the level of simple (ad hoc) constitutional changes that are more or less a normal process at national level: the introduction of majority decisions for internal market legislation (SEA 1986), the introduction of the three pillar structure and economic and monetary union (Treaty of Maastricht 1992) or the communitarisation of asylum and immigration policy as well as of judicial cooperation in civil matters or the introduction of legislative competencies (decisions and framework decisions) under the Third Pillar (Treaty of Amsterdam 1997) - these all elevated integration to a new, higher level and brought the Union each time a stage closer to a federal model. This may well apply less to the institutional reform initiated by the Treaty of Nice (not regarded largely as a great success), but we cannot ignore the wide-ranging developments in the Community's court system which Nice has achieved.

Under this rubric we must also include the Charter of Fundamental Rights of the European Union, a project with two unique characteristics: on the one hand the objective of formulating the Charter was specifically not to amend the Union's existing constitution; instead the fundamental rights already enshrined at Community level were to be closer defined and thereby to be made "more visible" ". - Secondly, the method of drafting the Charter was, to say the least, revolutionary in the context of Community law. The convocation of an assembly of representatives from Member State parliaments and governments as well as Community institutions, which was later to call itself a "Convention", instead of the usual intergovernmental conference,

Dr. Wolfgang Heusel, Director of the Academy of European Law Trier (ERA).

"Raum der Freiheit, der Sicherheit und des Rechts", cf. Art. 2 EU et passim. - In Dutch or Danish. the respective term is "rechtvaardigheid" or "retfærdigheid", notions which correspond to "justice" only in the substantive, not in the institutional sense which the English term also embraces (in German "Gerechtigkeit").

2 Conclusion 44 of the Cologne European Council. - The human rights "acquis" established mainly through case law of the European Court of Justice was to be documented, even if this was not to be legally consolidated; a formal adoption of the Charter (for example by incorporating it into the already existing Treaties) was no more than an option, not specifically included in the mandate formulated in Cologne. - For a detailed analysis of the Charter. its contents and the working method of the first Convention of. Heitset (et.). The Chatter of Fundamental Rights and Constitutional Development in the EU, ERA series of publications vol. 35. Cologne 2002. 
came very close to the classic and democratic system of constitution building. Given the pouvoir constituant nature of a Convention at national level, this has a very similar role in terms of constitution-building to that of an intergovernmental conference in relation to the conclusion of international treaties between sovereign states.

Both the project of drafting the EU's own Charter of Fundamental Rights and the use of the Convention method were an expression of the generally felt need for democratisation and greater transparency for the citizens of the European Union. The contents and method of the Charter project place it firmly in the sphere of European constitutional reform or constitution-building, even if in substantive terms no new European primary or constitutional law was intended to be created. This whole complex was made even clearer by the decision of the Nice European Council to set up a second "Convention" following the success of this method". The process of creating a European constitution now culminated in the submission of the draft Constitution of the EU by the second Convention under President Giscard d'Estaingt.

II.

These are fascinating developments witnessed in our times and much will have to be said about the general concept and detailed provisions of the draft Constitution being presented. At present, I want to make a few comments on the area of justice, the European legal area which is of particular interest to my institute.

First it seems particularly noteworthy that the draft Constitution refers to freedom, security and justice as part of the core policy area of the EU. The establishment of a European area of freedom, security and justice - a notion which first emerged in the Amsterdam Treaty in 1997 - has now been given a prominent place among the Union's objectives where it ranges second in Art. $\mathrm{I}^{5} 3^{5}$, and it is also listed second in the enumeration of the Union's principal policies in the area of shared competences ${ }^{6}$. This is the (provisional?) culmination of the impressive success story of an EU policy area which was only initiated by the Maastricht Treaty in 1992 and which has seen an enormous development at an accelerated pace since. It seems however all the more bizarre that this area has remained one of the classic examples of "enhanced cooperation", which is only a euphemism for the partial non-participation of three of the fifteen current Member States of which only two have the option of an opt-in as they please'.

3. The task of this second Convention, apart from drawing up a text for a unified constitution (or treaty) to replace already existing primary law, has been to evaluate the legal status of the Charter of Fundamental Rights. In the meantine consensus has emerged at a relatively early stage on the need to make the Charter an integral and legally binding part of the emerging European constitution: European Convention/Secretariat, doc. CONV 360/02 WG II 17 of 23.10.2002.

4 Cf. for parts I and II of the Convention http://european-convention.eu.inv/docs/Treaty/cv00797-re01 .en03.pdf (CONV 797/1/03 presented by the Praesidium on 12.6.03) and for parts III and IV http://europeanconvention.eu.int/docs/Treaty/cv00802.en03.pdf (CONV 802/03 presented on 13.6.03). - Debate in the Convention as well as in civil society was also boosted by the draft Constitution produced at the request of Commission President Prodi by a working group led by François Lamoureux (cf. "Pénélope"-. Projet de Constitution de l'Union européenne. edition avec commentaires, Paris 2003).

After "peace", the "values" of the Union and the "well-being of its peoples".

- Draft Art. I-13 \& 2 places the area of freedom, security and justice second after the internal market in a list of ten "principal areas" of shared competences.

It seems particularly absurd that Denmark, like all Member States, participates fully in "Third Pillar" based judicial cooperation in criminal matters and has participated in the adoption of so sensitive an instrument as the European arrest warrant simply through a Council decision, whereas in the area of judicial cooperation in civil and commercial matters it has, other than the UK and Ireland, constitutionally excluded itself from any opt-in so that the Brussels Convention on jurisdiction and enforcement in civil and commercial matters is still in force between Denmark and the other member states regardless of its substitution by the relevant "Brussels-I Regulation" between all other Member States (OJ 2001 L 12/1). 
My second observation is that for judicial cooperation, the pillar structure is still somehow reflected in the draft Constitution, although, and rightly so, the "multipillar" approach has been abandoned. Yet Chapter IV of the draft Constitution on the area of freedom, security and justice still strictly differentiates between judicial cooperation in criminal and in civil matters, seeming to leave no room for judicial cooperation in other areas such as administrative law where the need for cooperation is illustrated by the well-established EC competence to legislate in asylum and immigration matters ${ }^{8}$. No general principles of judicial cooperation are stipulated anywhere although there is scope and need for such approach, if we are to avoid being locked up in the civil or the criminal spheres - tertium non datur is in this case not just the logical consequence of an inevitable dichotomy but a harmful ignoring of other judicial areas. It would for example seem appropriate to list the principle of mutual recognition of judicial decisions, access to justice and judicial training as common principles of judicial cooperation in all areas and to elaborate in separate articles or sub-sections on specificities of judicial cooperation in distinct areas wherever appropriate 9 .

My third observation concerns judicial training, an area for which no express legal basis has existed so far and which is now for the first time mentioned at the level of primary law ${ }^{10}$. The draft Constitution expressly refers to judicial training, yet again separately and differentiating between civil and criminal matters". Whereas the difference in wording between the two seems irrelevant, the establishment for the first time of a clear legal basis for forthcoming EU legislation by qualified majority voting on the coordination of and cooperation in judicial training at EU level is a remarkable development in this rather sensitive area.

My last observation refers to the still incomplete and rather vague competence of the EU to legislate on substantive civil (private) law which the draft Constitution does not envisage developing and clarifying. Whereas draft Art. III-167 provides expressly for an EU competence to legislate on substantive criminal law ${ }^{12}$, draft Art. $165 \$ 2$ (c) contents itself by repeating what already appears in Art. 65(b) EC as far as civil law is concerned: harmonisation is only envisaged in the area of private international law ${ }^{13}$. Of course there are many areas of substantive private law already harmonised on a different legal basis, in particular as part of internal market

\& Cf. draft Ait. III-153 $\S 3,4$ on cooperation in either criminal or civil matters; section 3 of the Chapter deals exclusively with civil matters whereas section 4 looks only at criminal.

9 This approach was suggested to the Convention by Dominique de Villepin.

10 The ERA has accumulated considerable expertise in this area over the years, not least in its capacity as Secretariat of the European Judicial Training Network since this Network came into existence in October 2000. In fact the problems of the past in identifying an appropriate legal basis for setting up the Network officially at EU level by a single EU instrument seems to have led to the express reference to judicial cooperation in the draft Constitution. For further information on the EJTN mission and work cf. Heusel, A Network for European Judicial Training, ERA Forum 4/2001 (editorial).

" Whereas draft Art. III-I65 $\$ 2$ (h) aims at "ensuring ... support for the training of the judiciary and judicial staff" in civil matters, Art. III-166 $\$ 1$ (c) prefers to "encourage the training of the judiciary and judicial staff"; the instrument referred to is in both cases "a law or framework law". In fact this is another argument in favour of a general clause on judicial cooperation (see fn. 9 above).

12 Draft Art. III-167 provides for the adoption of framework laws in specific areas of crime by QMV; the list of crimes enumerated may be extended by unanimous decision of the Council with the consent of the EP.

13 The EU will "ensure" (Art 65(b) EC alternatively "promote" (draft Art. III-165 \& 2) "the compatibility of the rules applicable in the Member States concerning the conflict of laws and of jurisdiction", i.e. will permit the replacement of the Rome Convention by EU law. 
legislation, where for example a collection of not entirely consistent consumer protection instruments has developed half way towards a nucleus of European contract law and awaits codification. Given the long lasting debate on European contract law or even on a more general European civil law codification ${ }^{14}$ it would have seemed appropriate to provide at least a legal basis for a codification of contract law, company law and various other areas which have already received major attention during the development of the internal market, as has been suggested by members of the Convention ${ }^{15}$.

The draft Constitution has missed this timely opportunity. At least I would suggest the politically perfectly acceptable approach of redrafting Art. 165 to enable the EU to adopt a European civil code which would apply to all cross-border cases and could thus replace the relevant national rules of private international law ${ }^{16}$. Time would then show whether such a code would be effective enough to produce convergence in national private laws similar to the influence of $\mathrm{EC}$ competition law on national competition laws.

14 As for ERA's involvement in the debate, cf. the presentation of the different study groups on contract law (Fuchs et al. A Common Frame of Reference .... below p. ), and previously Barreth/Bernardeau, Towards a European Civil Code, ERA 2002; as well as ERA Forum 2/2002 (special issue on European contract law).

1s Cf. suggestions for amendment by Joschka Fischer and by Erwin Teufel in favour of EU competence in enumerated areas (Teufel wants to expressly exclude any further EU competence to legislate on civil law).

16 One could argue that Art. 65(b) EC in its present form already permits the adoption of such a European code to replace national PIL rules. 